\title{
KARAKTERISTIK FILM $\kappa$-KARAGINAN DENGAN PENAMBAHAN PLASTICIZER POLIETILEN GLIKOL
}

\section{Characteristics of $\kappa$-Carrageenan Film with Polyethylene Glycol as Plasticizer}

\author{
Dina Fransiska ${ }^{1 *}$, Giyatmi ${ }^{2}$, Hari Eko Irianto ${ }^{1}$, Muhamad Darmawan ${ }^{1}$, dan Susiana Melanie ${ }^{1}$ \\ ${ }^{1}$ Balai Besar Riset Pengolahan Produk dan Bioteknologi Kelautan dan Perikanan, \\ JI. KS Tubun Petamburan VI, Slipi, Jakarta, Indonesia \\ ${ }^{2}$ Fakultas Teknologi Industri Pertanian, Universitas Sahid, \\ JI. Prof. DR. Soepomo, Tebet, Jakarta, Indonesia \\ *Korespondensi Penulis: dinanomo@gmail.com
}

Diterima: 5 Oktober 2017; Direvisi: 6 April 2018; Disetujui: 5 Juni 2018

\begin{abstract}
ABSTRAK
Bahan plastik biodegradable saat ini sedang populer dikembangkan untuk menggantikan plastik kemasan konvensional yang tidak ramah lingkungan. Penelitian ini bertujuan untuk mengetahui pengaruh penambahan polietilen glikol (PEG) terhadap karakteristik film berbahan dasar $\kappa$-karaginan. $\kappa$-karaginan yang digunakan dalam formulasi pembuatan film yaitu sebanyak $1,5 \%(b / v)$, sedangkan konsentrasi PEG yang ditambahkan bervariasi yaitu 2, 4, 6, 8, dan $10 \%$ (b/ b). Larutan dipanaskan hingga suhu $85^{\circ} \mathrm{C}$ kemudian dicetak dalam bentuk film tipis, lalu didinginkan dan dikeringkan dengan oven hingga didapatkan berat konstan. Film yang diperoleh kemudian dilakukan analisis termal, kuat tarik, elongasi dan water vapor transmission rate (WVTR). Hasil penelitian menunjukkan bahwa semakin besar polietilen glikol yang ditambahkan pada film karaginan dapat meningkatkan titik leleh dan entalpi, tetapi menurunkan nilai kuat tariknya, dan juga tidak mempengaruhi nilai WVTR. Penambahan PEG sampai konsentrasi $4 \%$ juga meningkatkan nilai elongasi film. Dari hasil pengujian diperoleh jumlah optimal penambahan PEG yaitu sebesar $4 \%$ dengan nilai kuat tarik sebesar $0,86 \pm 0,16 \mathrm{MPa}$, elongasi $25,40 \pm 6,64 \%$, dan WVTR $116,02 \pm 8,00 \mathrm{~g} / \mathrm{m}^{2} / 24$ jam.
\end{abstract}

KATA KUNCI: biodegradable film, $\kappa-k a r a g i n a n$, polietilen glikol

\begin{abstract}
Biodegradable plastic materials are currently being developed in broader scope, particularly to replace non-biodegradable plastic packaging. This study aimed to determine the effect of polyethylene glycol (PEG) concentration on the characteristics of $\kappa$-carrageenan based film. $\kappa$ carrageenan used in the film preparation was $1.5 \%(w / v)$ while PEG was added at various concentration i.e. 2, 4, 6, 8, and $10 \%(\mathrm{~W} / \mathrm{w})$. The solution was heated up to $85^{\circ} \mathrm{C}$ and casted into thin film, then cooled and dried using oven until reached a constant weight. The film produced was then tested for its thermal behaviour, tensile strength, elongation and water vapor transmission rate (WVTR). The results showed that the increase of concentration of polyethylene glycol added to the carrageenan film could increase the melting point and enthalpy value as well as elongation of the film. However, it decreased the tensile strength, and did not affect to the WVTR. The optimum concentration of PEG added was found at $4 \%$ with the tensile strength of $0.86 \pm 0.16 \mathrm{MPa}$, elongation of $25.40 \pm 6.64 \%$, and WVTR of $116.02 \pm 8.00 \mathrm{~g} / \mathrm{m}^{2} / 24$ hours.
\end{abstract}

KEYWORDS: biodegradable film, א-carrageenan, polyethylene glycol

\section{PENDAHULUAN}

Salah satu kebutuhan primer manusia adalah kebutuhan pangan, dan produk pangan semakin berkembang sejalan dengan peningkatan ilmu pengetahuan dan teknologi serta meningkatnya kebutuhan pangan bagi masyarakat. Hal tersebut juga mencakup aspek pengemasan yang menjadi salah satu komponen penting dalam industri pangan. Kemasan pangan merupakan bahan yang digunakan untuk mewadahi dan/atau membungkus bahan pangan baik yang bersentuhan langsung maupun tidak 
langsung dengan pangan (BPOM, 2014). Bahan pengemas untuk produk pangan yang banyak digunakan dan dijumpai di masyarakat adalah plastik.

Plastik merupakan polimer berbasis karbon yang dibuat dengan menggunakan bahan baku yang berasal dari cadangan bahan bakar fosil (Gade, Tulasi \& Bhai, 2013). Produk plastik kemasan saat ini sangat banyak beredar di pasaran, salah satunya adalah LDPE (low density polyethylene). Plastik LDPE termasuk polimer yang tidak dapat terdegradasi, sehingga berpotensi menimbulkan pencemaran lingkungan dan mengancam ekosistem (Darni \& Utami, 2010). Di Indonesia, menurut data statistik persampahan domestik Indonesia, jenis sampah plastik menduduki peringkat kedua sebesar 5,4 juta ton per tahun atau 14 persen dari total produksi sampah. Dengan demikian, plastik telah menggeser sampah jenis kertas menjadi peringkat ketiga dengan jumlah 3,6 juta ton per tahun atau $9 \%$ dari jumlah total produksi sampah (Inswa, 2013). Di samping itu, penggunaan plastik pada produk pangan juga dapat menyebabkan permasalahan pada kesehatan manusia. Kemasan plastik menyimpan kelemahan yaitu kemungkinan terjadinya migrasi zat monomer dari bahan plastik ke dalam makanan. Semakin lama kontak antara makanan tersebut dengan kemasan plastik, menyebabkan jumlah monomer yang bermigrasi dapat makin tinggi (Koswara, 2006).

Penurunan potensi sumber daya bahan bakar fosil diiringi dengan peningkatan permintaan masyarakat untuk bahan kemasan ramah lingkungan menyebabkan dilakukannya berbagai upaya penelitian tentang pengembangan plastik biodegradable dari sumber daya yang berkelanjutan (Meylemans et al., 2013). Salah satu alternatif yang potensial untuk dikembangkan pada masa yang akan datang adalah pembuatan plastik dengan menggunakan bahan organik (bioplastik) yang dapat terdegradasi secara alamiah. Banyak keuntungan yang didapatkan dengan penggunaan bioplastik dibandingkan plastik konvensional, seperti mengurangi ketergantungan pada bahan bakar fosil, tidak beracun, mudah untuk didaur ulang, membutuhkan lebih sedikit energi untuk menghasilkannya, dan ramah lingkungan (Rajendran et al., 2012).

Polisakarida seperti pektin (Šešlija, Nešiæ, Ružiæ, \& Krušiæ, 2017), selulosa (Bedane, Eiæ, Farmahini-Farahani, \& Xiao, 2015), khitosan (Rachmawati, Triwibowo, \& Widianto, 2015), kitin (Shimojo et al., 2010), pati (Lafargue, Lourdin, \& Doublier, 2007; Slavutsky \& Bertuzzi, 2014), alginat (Darmawan, 2007), karagenan (Irianto, Darmawan, \& Mindarwati, 2006) dan galaktomanan (Figueiro, 2004) telah dipelajari sebagai bahan potensial untuk biofilm.
Berbagai jenis sumber tanaman yang telah digunakan dalam pembuatan bioplastik adalah tanaman berpati, seperti gandum, tepung jagung, padi, ubi jalar, sorgum dan turunan selulosa, yang menyumbang hampir $80 \%$ dari pasar bioplastik. Namun kelemahan dari penggunaan bahan baku berbasis tanaman adalah rendahnya biomassa yang dihasilkan, membutuhkan waktu yang relatif lama untuk pertumbuhannya, serta dapat menganggu rantai makanan untuk manusia, mengingat bahan-bahan tersebut masih menjadi konsumsi utama manusia. Sumber lain yang memiliki potensi untuk digunakan sebagai bahan pembuatan bioplastik adalah rumput laut. Keuntungan dari penggunaan rumput laut sebagai bahan bioplastik adalah mampu dihasilkan dalam jumlah yang banyak, harga yang relatif murah, dan bersifat non toksik, serta dapat menghasilkan bioplastik yang memiliki karakteristik menyerupai plastik konvensional (Rajendran et al., 2012)

Indonesia memiliki sumber daya rumput laut yang sangat besar. Berdasarkan data statistik dari Kementerian Kelautan dan Perikanan, total nilai produksi rumput laut dalam negeri mencapai US $\$ 1,12$ juta pada 2015. Dari nilai tersebut, sebanyak 21\% atau 236,9 ribu ton diekspor ke berbagai negara, dengan komposisi sebanyak $97 \%$ berupa bahan baku dan sisanya berupa produk olahan (Anon., 2017). Melihat ketersediaan bahan baku yang sangat besar dan peluang pengembangan industri bioplastik yang sangat prospektif maka teknologi pembuatan bioplastik berbahan dasar rumput laut merah sebagai bahan pengemas produk pangan memiliki potensi yang besar untuk dikembangkan, karena selain dapat mengurangi permasalahan lingkungan, juga mendapatkan keuntungan ekonomi yang tinggi dari hasil produksi bioplastik.

Beberapa penelitian terkait dengan pembuatan bioplastik dari rumput laut telah dilakukan. Plastik berbahan baku rumput laut maupun pati dikategorikan ke dalam kategori plastik hydrocolloidal (Hollingworth, 2010). Plastik hydrocolloidal memiliki kekurangan dibandingkan dengan bahan plastik lainnya yaitu rendahnya resistensi terhadap air serta memiliki sifat mekanis yang rendah apabila digunakan sendiri atau tanpa adanya bahan tambahan lain seperti plasticizer ataupun bahan lainnya (Abdorreza, Cheng, \& Karim, 2011; Kokoszka, Debeaufort, Hambleton, Lenart, \& Voilley, 2010; Phan, Debeaufort, Luu, \& Voilley, 2005; Prachayawarakorn \& Pomdage, 2014). Plastik film yang dibuat dari rumput laut merah memiliki sifat penghalang terhadap kelembaban yang lebih baik dibandingkan dengan plastik film yang dibuat dari bahan pati singkong (Prachayawarakorn \& Pomdage, 2014) 
Penelitian ini dilakukan untuk mengetahui pengaruh konsentrasi polietilen glikol pada proses pembuatan film dari kappa karaginan ( $\kappa$-karaginan) terhadap karakteristik mutu film yang dihasilkan.

\section{BAHAN DAN METODE}

\section{Bahan}

Bahan untuk pembuatan film yaitu $\kappa$-karaginan yang diekstrak dari rumput laut merah Eucheuma cottonii yang diperoleh dari Serang, Banten, dan plasticizer yaitu polietilen glikol (PEG) 400 (ID Chem, Korea).

\section{Metode}

\section{Ekstraksi dan karakterisasi k-karaginan}

Ekstraksi $\kappa$-karaginan dilakukan dengan metode Hakim, Wibowo, Arfini, \& Peranginangin (2011). Rumput laut kering yang telah dicuci dengan air, direbus dalam larutan $\mathrm{KOH} 8 \%$ dengan perbandingan $1: 6(\mathrm{~b} / \mathrm{v})$ pada suhu $\pm 60-65^{\circ} \mathrm{C}$ selama 120 menit. Setelah proses perlakuan alkali, rumput laut dicuci hingga mendekati $\mathrm{pH}$ netral. Rumput laut direbus kembali dengan perbandingan rumput laut:air $=1: 20$ (b/v) pada suhu $\pm 85-90^{\circ} \mathrm{C}$ selama 120 menit sambil diaduk. Ketika proses ekstraksi telah mencapai 60 menit, ditambahkan celite 3\% (b/v), kemudian filtrat hasil ekstraksi disaring menggunakan filter press. Filtrat didiamkan selama semalam hingga mencapai suhu ruang $\left( \pm 25^{\circ} \mathrm{C}\right)$. Selanjutnya filtrat dimasukkan dalam larutan $\mathrm{KCl} 1 \%(\mathrm{~b} / \mathrm{v})$ dengan perbandingan $1: 2$ (b/v) sambil diaduk hingga terbentuk gel karaginan. Gel к-karaginan kemudian ditekan menggunakan alat press manual dan dikeringkan di bawah sinar matahari hingga mencapai berat konstan.

$\kappa$-karaginan yang dihasilkan dikarakterisasi yang meliputi kadar air, kadar abu, kadar abu tak larut asam (AOAC, 1999), dan kadar sulfat (Anon., 1986).

\section{Preparasi dan karakterisasi film}

Preparasi film dilakukan pertama dengan melarutkan $\kappa$-karaginan dengan aquades lalu dipanaskan sampai suhu mencapai $80^{\circ} \mathrm{C}$, selanjutnya ke dalam larutan ditambahkan plasticizer (PEG 400) sesuai dengan formulasi pada Tabel 1. Campuran $\kappa$-karaginan dan PEG masing-masing dilarutkan ke dalam $100 \mathrm{ml}$ aquades, sambil dipanaskan pada suhu $80^{\circ} \mathrm{C}$. Larutan kemudian dituang ke dalam cetakan akrilik berukuran $16 \times 16$ $\mathrm{cm}$, kemudian dikeringkan dengan oven pada suhu $40^{\circ} \mathrm{C}$ selama $20 \mathrm{jam}$.

\section{Pengamatan}

Pengamatan mutu film meliputi water vapor transmission rate yang dilakukan dengan metode gravimetri (Razzaq et al., 2016), sifat termal menggunakan differential scanning calorimetri (DSC) (Razzaq et al., 2016), stabilitas termal menggunakan simultaneous termal analysis (STA) (Razzaq et al., 2016), ketebalan dengan jangka sorong digital Mitutoyo (ASTM International, 2013), kuat tarik (ASTM, 2012) dan elongasi dengan alat TAXT texture analyzer (ASTM, 2012).

\section{HASIL DAN BAHASAN}

\section{Karakteristik Bahan Baku Rumput Laut dan Karaginan}

Pengujian kadar air bertujuan untuk mengetahui banyaknya air yang terkandung dalam rumput laut. Tingginya kadar air rumput laut dimungkinkan mampu mempengaruhi tumbuh kembang mikroorganisme, bakteri dan jamur pencemar rumput laut. Kadar air, CAW dan impurities rumput laut disajikan pada Tabel 2. Rumput laut $E$. cottonii memiliki kadar air sebesar $36,66 \pm 0,98 \%$. Nilai kadar air tersebut telah melampaui SNI 2690:2015 yaitu maksimal 30,0\%. Tingginya kadar air rumput laut kemungkinan disebabkan faktor proses

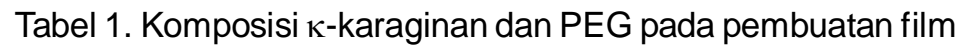

Table 1. $\kappa$-carrageenan-PEG compositions in film preparation

\begin{tabular}{ccc}
\hline Formula/Formula & $\begin{array}{c}\boldsymbol{\kappa} \text {-karaginan (\%) (b/v)/ } \\
\boldsymbol{\kappa} \text {-carrageenan (\%) (w/v) }\end{array}$ & $\begin{array}{c}\text { PEG } \mathbf{4 0 0}(\%)(\mathbf{b} / \mathbf{v}) / \\
\text { PEG } \mathbf{4 0 0}(\%)(\boldsymbol{w} / \mathbf{v})\end{array}$ \\
\hline 1 & 1.5 & 0 \\
2 & 1.5 & 2 \\
3 & 1.5 & 4 \\
4 & 1.5 & 6 \\
5 & 1.5 & 8 \\
6 & 1.5 & 10 \\
\hline
\end{tabular}


Tabel 2. Kualitas bahan baku rumput laut

Table 2. Quality of seaweed as raw material

\begin{tabular}{lcc}
\hline \multicolumn{1}{c}{ Parameter/Parameters } & SNI 2690:2015* & E. cottonii \\
\hline Kadar air/Moisture content & Maks 30.0\% & $36.66 \pm 0.98 \%$ \\
Clean anhydrous weed (CAW) & Min 50.0\% & $37.14 \pm 1.50 \%$ \\
Pengotor/Impurities & Maks 3.0\% & $0.84 \pm 0.10 \%$ \\
\hline
\end{tabular}

Keterangan/Note: *(BSN, 2015)

pengeringan yang tidak maksimal dan faktor kelembaban penyimpanannya. Menurut Winarno (1996), kadar air rumput laut dapat dipengaruhi proses pengeringannya.

Pengujian CAW dilakukan untuk mengetahui tingkat kemurnian rumput laut. Nilai CAW tersebut belum memenuhi SNI 2690:2015 yaitu minimal 50,0\%. Rendahnya CAW tersebut dimungkinkan karena kadar air rumput laut yang masih tinggi.

Pengujian impurities bertujuan untuk mengetahui tingkat kebersihan rumput laut dari pengotor, pasir, garam laut dan batu karang yang melekat. Nilai impurities rumput laut $E$. cottonii telah memenuhi SNI 2690:2015 yaitu maksimal $0,84 \pm 0,10 \%$. Pada Tabel 3 disajikan karakter fisikokimia $\kappa$-karaginan yang dihasilkan.

\section{Karakteristik Film}

\section{Deskripsi film}

Deskripsi film kappa karaginan-PEG dapat dilihat pada Tabel 4. Film $\kappa$-karaginan tanpa penambahan polietilen glikol menghasilkan film yang kusam, tidak berminyak dan tidak mengkilat. Pada film $\kappa$-karaginan dengan penambahan PEG sampai 8\% menghasilkan film yang mengkilat, sedikit berminyak.

\section{Analisis termal}

Gambar 1 dan 2 menunjukkan hasil analisis termal. Analisis termal menggunakan STA merupakan suatu teknik analisis, dengan menentukan perbedaan

Tabel 3. Mutu fisikokimia $\kappa$-karaginan

Table 3. The physicochemical quality of $\kappa$-carrageenan

\begin{tabular}{lc}
\hline \multicolumn{1}{c}{ Parameter/Parameters } & Nilai/Value \\
\hline Kekuatan gel/Gel strength $\left(\mathrm{g} / \mathrm{cm}^{2}\right)$ & $450.00 \pm 7.50$ \\
Viskositas/Viscocity (cPs) & $15.00 \pm 2.50$ \\
Kadar air/Moisture content (\%) & $22.16 \pm 2.29$ \\
Kadar abu/Ash content (\%) & $34.18 \pm 1.92$ \\
Kadar abu tak larut asam/Acid Insoluble ash content (\%) & $0.71 \pm 0.15$ \\
Kadar sulfat/Sulphate content (\%) & $1.05 \pm 0.02$ \\
\hline
\end{tabular}

Tabel 4. Deskripsi film $\kappa$-karaginan

Table 4. Description of $\kappa$-carrageenan film

\begin{tabular}{cl}
\hline Kode Sampel/Sample code & \multicolumn{1}{c}{ Deskripsi/Description } \\
\hline K0 & Kusam, tidak berminyak, tidak mengkilat/ opaque, not greasy, not shiny \\
K2 & Bening, tidak berminyak, mengkilat/ transparent, not greasy, shiny \\
K4 & Bening, tidak berminyak, mengkilat/ transparent, not greasy, shiny \\
K6 & Bening, tidak berminyak, mengkilat/ transparent, not greasy, shiny \\
K8 & Bening, sedikit berminyak, mengkilat/ transparent, slightly greasy, shiny \\
\hline
\end{tabular}

Keterangan/Note:

K0: $\kappa$-karaginan 1,5\%, tanpa PEG/1.5\% $\kappa$-carrageenan, without PEG

K2: $\kappa$-karaginan 1,5\%, PEG 2\%/1.5\% $\kappa$-carrageenan, 2\% PEG

K4: $\kappa$-karaginan 1,5\%, PEG 4\%/1.5\% $\kappa$-carrageenan, 4\% PEG

K6: $\kappa$-karaginan 1,5\%, PEG 6\%/1.5\% -carrageenan, 6\% PEG

K8: kkaraginan 1,5\%, PEG $8 \% / 1.5 \% \kappa$-carrageenan, $8 \%$ PEG 
temperatur $(\Delta \mathrm{T})$ antara sampel dan bahan pembanding, yang terlihat perbedaannya pada sumbu Y. Sedangkan sumbu X merupakan kenaikan pemanasan sampel dan pembanding. Gambar 1 menunjukkan bahwa film karaginan tanpa PEG kehilangan berat $50 \%$ pada suhu $348{ }^{\circ} \mathrm{C}$, dan sisa residu $41,30 \%$ pada suhu $500{ }^{\circ} \mathrm{C}$. Gambar 2 menunjukkan bahwa film karaginan dengan $6 \%$ PEG kehilangan berat $50 \%$ pada suhu $348{ }^{\circ} \mathrm{C}$ dan sisa residu $8,72 \%$ pada suhu $500{ }^{\circ} \mathrm{C}$.

Film $\kappa$-karaginan tanpa PEG yang menunjukkan luas area 223,343 mJ, menghasilkan entalpi sebesar $15,5690 \mathrm{~J} / \mathrm{g}$ pada titik leleh $225,20^{\circ} \mathrm{C}$; sementara film $\kappa$-karaginan dengan konsentrasi 6\% PEG yang menunjukkan luas area 8,840 $\mathrm{mJ}$ (yang jauh lebih kecil dibandingkan film $\kappa$-karaginan tanpa $P E G$ ) menghasilkan entalpi sebesar $0,7596 \mathrm{~J} / \mathrm{g}$ pada titik leleh $244,32{ }^{\circ} \mathrm{C}$. Penambahan konsentrasi PEG terlihat secara nyata meningkatkan titik leleh dan menurunkan entalpi pada film kappa karaginan. Šešlija et al. (2017) menyatakan bahwa terjadinya peningkatan titik leleh dan pergeseran nilai entalpi disebabkan karena penambahan PEG telah mengurangi gaya antar molekul karaginan. Dengan meningkatnya titik leleh ini diharapkan film karaginan ini dapat digunakan pada produk-produk pangan yang memerlukan pemanasan pada batas suhu tertentu.

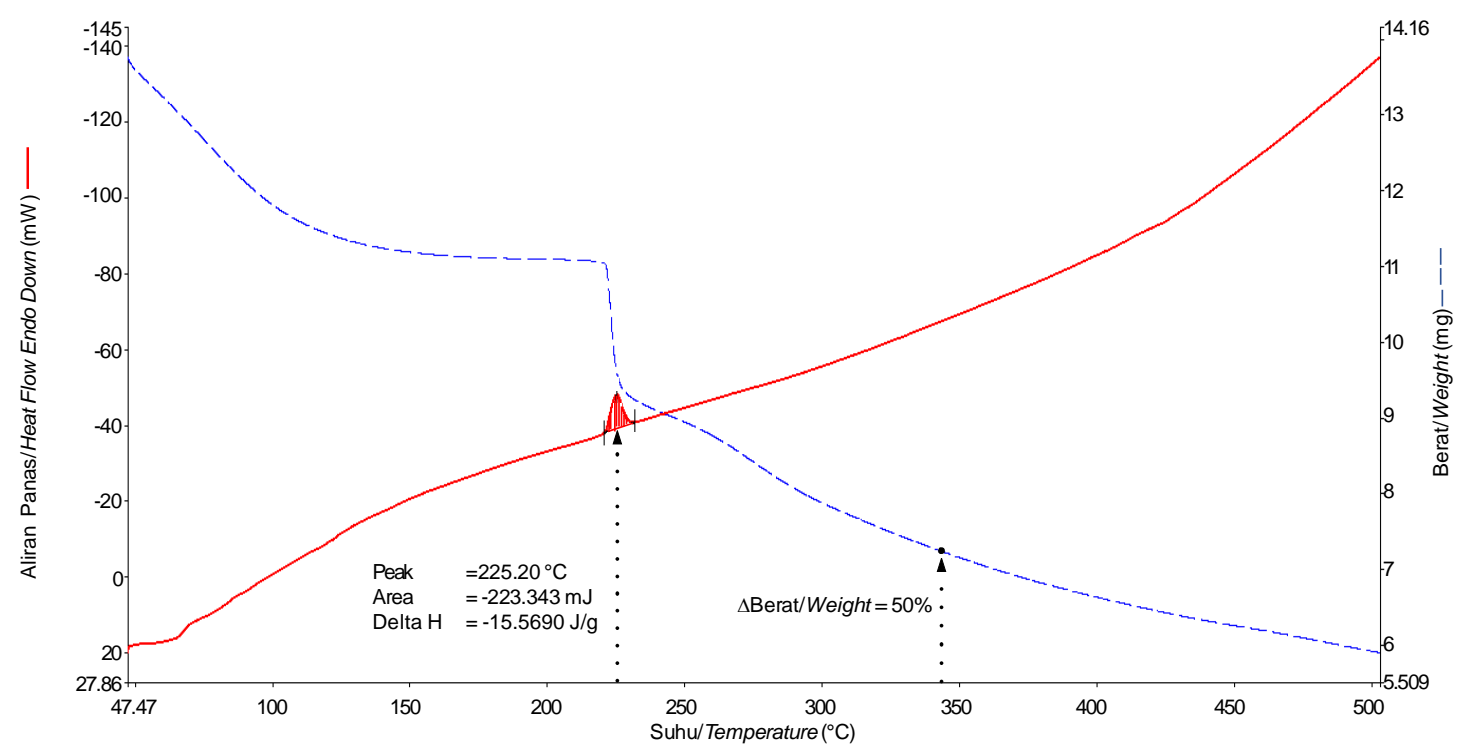

Gambar 1. Film $\kappa$-karaginan tanpa plasticizer

Figure 1. $\mathrm{\kappa}$-carrageenan film without plasticizer

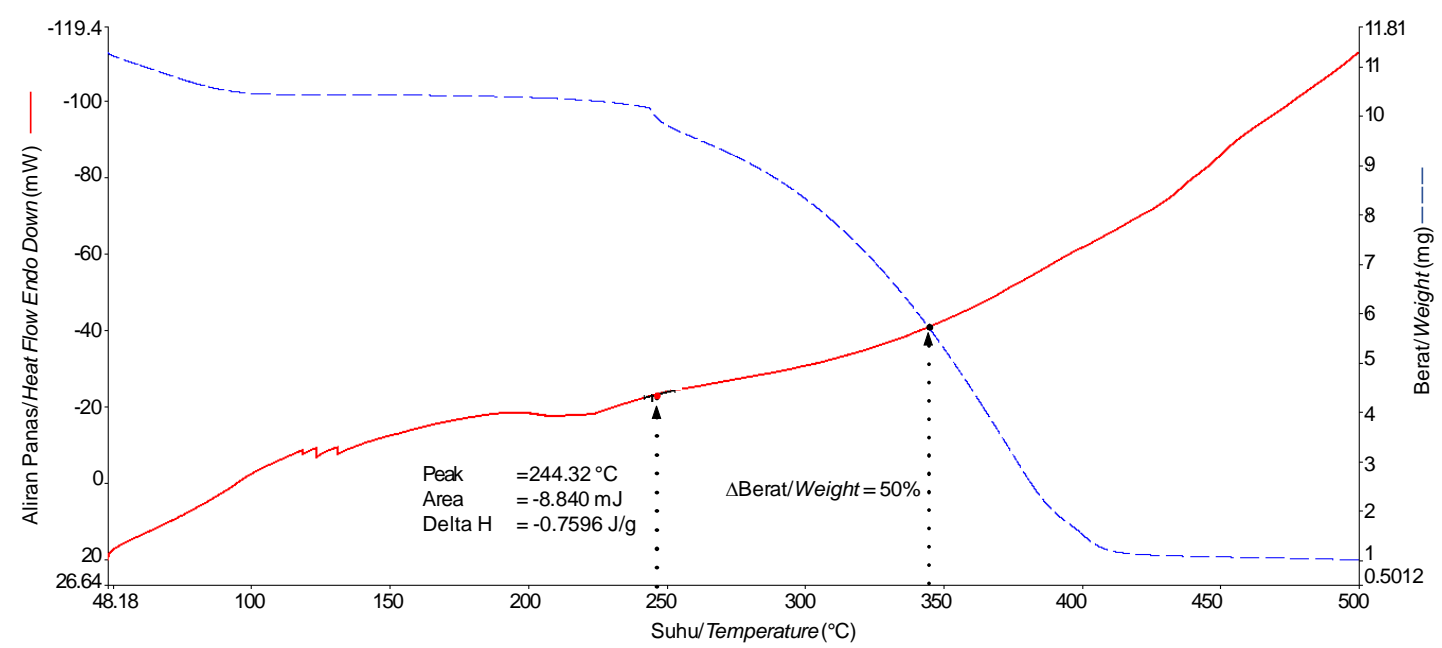

Gambar 2. Film $\kappa$-karaginan dengan 6\% PEG

Figure 2. $\kappa$-carrageenan film with $6 \%$ PEG 


\section{Kekuatan mekanik}

Sifat mekanik film merupakan karakteristik utama yang mempunyai peranan penting dalam aplikasinya sebagai kemasan. Kekuatan mekanik film diuji dengan uji kuat tarik dan elongasi. Hasil analisis kuat tarik dan elongasi terlihat pada Gambar 3 dan 4. Pada Gambar 3 terlihat bahwa film $\kappa$-karaginan tanpa PEG memiliki sifat kuat namun tidak elastis, dengan kuat tarik 24,850 MPa dan elongasi 4,2\%. Film $\kappa$-karaginan dengan penambahan PEG memiliki kuat tarik yang lebih rendah dibandingkan tanpa penambahan PEG. Hal serupa dilaporkan oleh Šešlija et al., (2017), bahwa penambahan PEG dapat menurunkan kuat tarik. Hasil ini dapat dijelaskan bahwa penambahan PEG telah mengurangi gaya antarmolekul karaginan.

Elongasi film $\kappa$-karaginan mengalami peningkatan sampai penambahan 4\% PEG. Pada penambahan $6 \%$ PEG, elongasi tidak berbeda nyata dengan penambahan 4\% PEG. Kemudian menurun pada penambahan $8 \%$ dan $10 \%$ (Gambar 4). Adanya PEG sebagai plasticizer akan mengurangi gaya antarmolekul dan menurunkan kuat tarik (Sogiana, Tetty, \& Ahmad, 2013) serta menurunkan gaya antarmolekul sepanjang rantai polimer karaginan sehingga meningkatkan kelenturan (Zhong et al., 2008). Namun penambahan PEG lebih dari $6 \%$ menurunkan nilai elongasi film $\kappa$-karaginan.

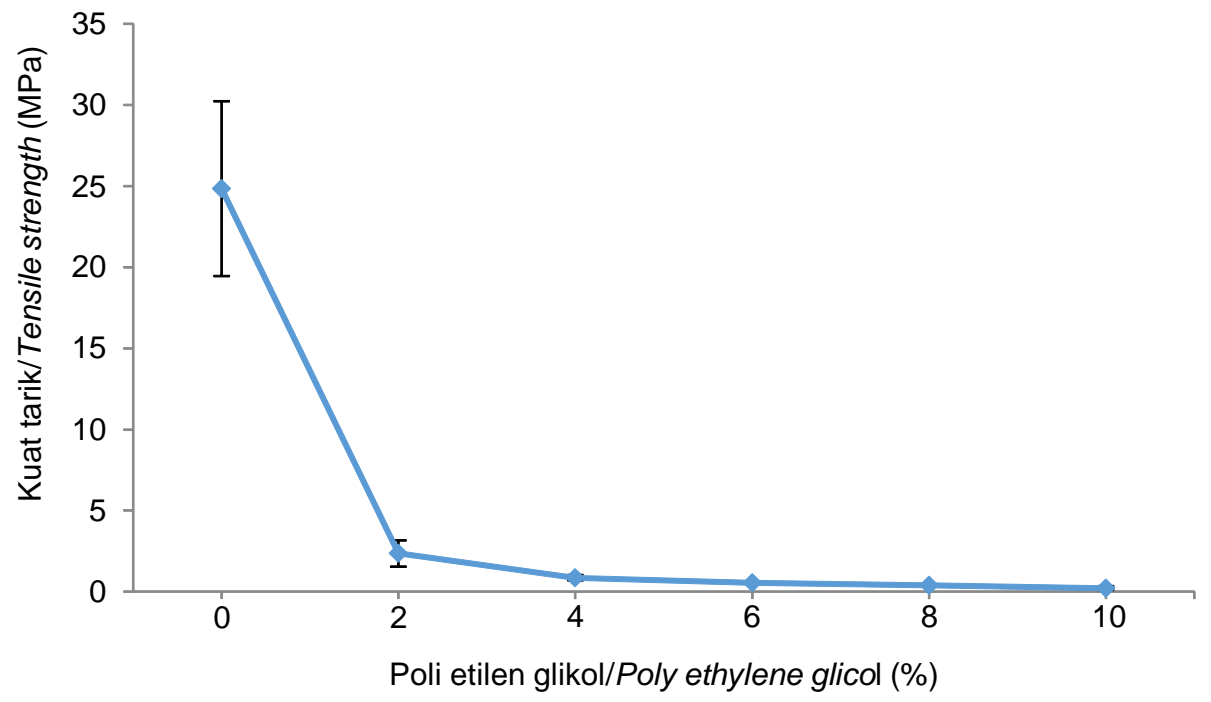

Gambar 3. Kuat tarik film $\kappa$-karaginan-PEG

Figure 3. The tensile strength of $\kappa$-carrageenan-PEG film

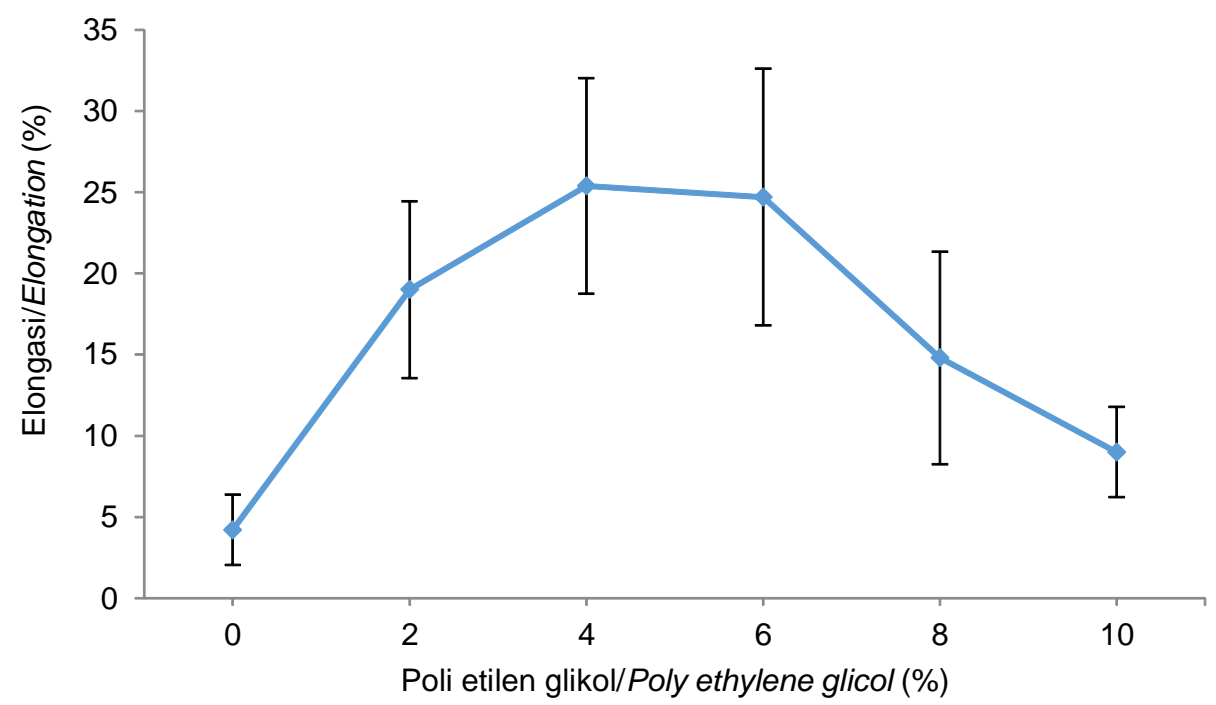

Gambar 4. Elongasi film $\kappa-k a r a g i n a n-P E G$

Figure 4. The elongation at break of $\kappa$-carrageenan-PEG film 


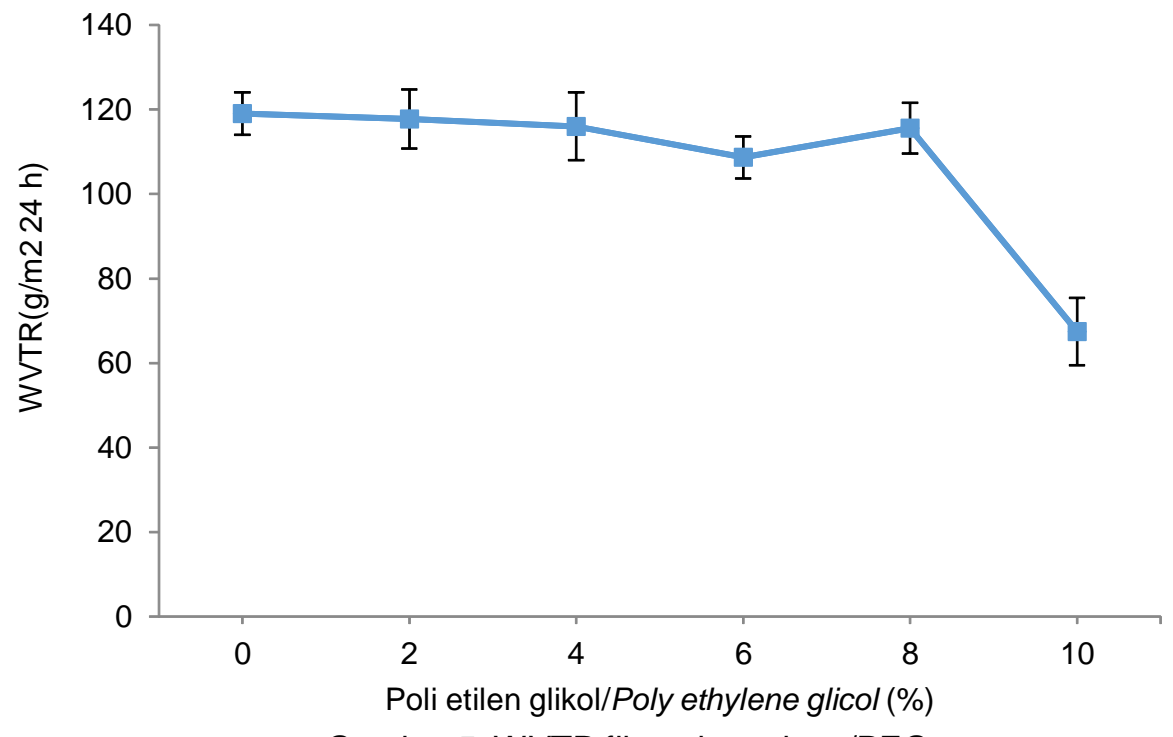

Gambar 5. WVTR film $\kappa$-karaginan/PEG

Figure 5. The WVTR of $\kappa$-carrageenan/PEG film

\section{WVTR}

Water vapor transmission rate adalah jumlah uap air yang melalui permukaan film per luas area. Nilai WVTR film karaginan-PEG berkisar antara $67,45 \pm 8,00-117,75 \pm 7,00 \mathrm{~g} / \mathrm{m}^{2} / 24 \mathrm{jam}$. Hasil analisis menunjukkan bahwa terjadi penurunan nilai WVTR yang signifikan pada film karaginan dengan penambahan PEG $10 \%$. Sedangkan film karaginan dengan penambahan PEG 0-8\% tidak berpengaruh terhadap nilai WVTR. Umumnya film yang terbuat dari polisakarida mempunyai nilai transmisi uap air yang tinggi. Nilai WVTR edible film yang diperoleh pada penelitian ini lebih rendah bila dibandingkan hasil penelitian Irianto, Darmawan dan Mindarwati (2006) yang membuat komposit edible film karaginan/tepung tapioka/lilin lebah dengan menggunakan gliserol sebagai plasticizer yaitu sebesar 746,2-1117,4 g/m²/ 24 jam.

\section{KESIMPULAN}

Berdasarkan penelitian yang telah dilakukan dapat disimpulkan bahwa penambahan polietilen glikol meningkatkan titik leleh dan entalpi film karaginan. Penambahan PEG sampai 4\% dapat meningkatkan nilai elongasi film yang dihasilkan. Dari karakteristik film yang dihasilkan secara keseluruhan, film karaginan dengan penambahan PEG sebesar 4\% adalah yang terbaik karena memiliki nilai elongasi tertinggi $25,40 \pm 6,64 \%$, kuat tarik sebesar $0,86 \pm 0,16$ $\mathrm{MPa}$, dan WVTR sebesar $116,02 \pm 8,00 \mathrm{~g} / \mathrm{m}^{2} / 24 \mathrm{jam}$.

\section{DAFTAR PUSTAKA}

Abdorreza, M. N., Cheng, L. H., \& Karim, A. A. (2011). Food Hydrocolloids Effects of plasticizers on thermal properties and heat sealability of sago starch films. Food Hydrocolloids, 25(1), 56-60. https://doi.org/ 10.1016/j.foodhyd.2010.05.005

Anonymous. (1986). Specification for Identity purity of Certain food additives (FAO and Nutrition paper).

Anonymous. (2017). Ekspor Rumput Laut Turun 30\%. Media Indonesia. Retrieved from http:// mediaindonesia.com/news/read/87002/eksporrumput-laut-turun-30/2017-01-11.

Association of Official Agricultural Chemists (AOAC). (1999). Official Methods of Analysis the Association (15th. Ed.). Virginia, AOAC Inc. Arlington.

American Society for Testing Materials (ASTM). (2012). ASTM Standard D882. Standard test method for tensile properties of thin plastic sheeting. West Conshohocken, PA: ASTM International. https:// doi.org/10.1520/D0882-12

American Society for Testing Materials (ASTM). (2013). Standard Test Method for Mass Per Unit Area of Paper and Paperboard of Aramid Papers (Basis Weight). West Conshohocken, Pennsylvania.

Bedane, A. H., Eiæ, M., Farmahini-Farahani, M., \& Xiao, H. (2015). Water vapor transport properties of regenerated cellulose and nanofibrillated cellulose films. Journal of Membrane Science, 493, 46-57. https://doi.org/10.1016/j.memsci.2015.06.009

Badan Pengawas Obat dan Makanan (BPOM). (2014). Cermat Memilih Kemasan Pangan Untuk Menghindari Keracunan. Retrieved from http:// ik.pom.go.id/v2014/artikel/cermat-memilihkemasan-pangan.pdf 
Badan Stardisasi Nasional (BSN). (2015). SNI 2690:2015 Rumput laut kering. In Standar Nasional Indonesia. Badan Standardisasi Nasional.

Darmawan, M. (2007). Karakteristik Edible Film dari Komposit Alginat, Gluten, dan Lilin Lebah (Beeswax). Jurnal Pascapanen Dan Bioteknologi Kelautan Dan Perikanan, 2(1), 19-26.

Darni, Y., \& Utami, H. (2010). Studi Pembuatan dan Karakteristik Sifat Mekanik dan Hidrofobisitas Bioplastik dari Pati Sorgum, Jurnal Rekayasa Kimia dan Lingkungan, 7(4), 88-93.

Figueiro, S. D. (2004). On the physico-chemical and dielectric properties of glutaraldehyde crosslinked galactomannan - collagen films, 56, 313-320. https:/ /doi.org/10.1016/j.carbpol.2004.01.011

Gade, Tulasi, M. S., \& Bhai, V. A. (2013). Seaweed: A Novel Biomaterial. International Journal of Pharmacy and Pharmaceutical Sciences, 5(2).

Hakim, A. R., Wibowo, S., Arfini, F., \& Peranginangin, R. (2011). Pengaruh Perbandingan Air Pengekstrak, Suhu Presipitasi, dan Konsentrasi Kalium Klorida (KCL) Terhadap Mutu Karaginan. Jurnal Pascapanen Dan Bioteknologi Kelautan Dan Perikanan, 6(1), 112.

Hollingworth, C. S. (2010). Food Hydrocolloids: Characteristics, Properties and Structures, Food Science and Technology. In Food Hydrocolloid Edible Films and Coatings. New York: Nova Science Publishers, Inc.

Inswa. (2013). Fenomena Sampah Plastik di Indonesia. Retrieved from http://inswa.or.id/?p=1026

Irianto, H. E., Darmawan, M., \& Mindarwati, E. (2006). Pembuatan Edible Film Dari Komposit Karaginan, Tepung Tapioka dan Lilin Lebah (Beeswax). Jurnal Pascapanen Dan Bioteknologi Kelautan Dan Perikanan, 1(2), 93-100.

Kokoszka, S., Debeaufort, F., Hambleton, A., Lenart, A., \& Voilley, A. (2010). Protein and glycerol contents affect physico-chemical properties of soy protein isolatebased edible fi Ims. Innovative Food Science and Emerging Technologies, 11(3), 503-510. https:// doi.org/10.1016/j.ifset.2010.01.006

Koswara. (2006). Bahaya di balik Kemasan Plastik. Retrieved from http://ebookpangan.com

Lafargue, D., Lourdin, D., \& Doublier, J. (2007). Filmforming properties of a modified starch / j carrageenan mixture in relation to its rheological behaviour, 70, 101-111. https://doi.org/10.1016/ j.carbpol.2007.03.019

Meylemans, Benjamin, Harvey, Reams, Guenthner, Cambrea, Groshens, Baldwin, Garrison, M. (2013). Synthesis, Characterization, and Cure Chemistry of Renewable Bis(cyanate) Esters Derived from 2-
Methoxy-4-Methylphenol. Biomacromolecules, 14(3), 771-780. https://doi.org/DOI: 10.1021/bm3018438

Phan, T.D., Debeaufort, F., Luu, D. and Voilley, A. (2005). Functional properties of edible agar-based and starch-based Ims for food quality preservation. Journal of Agricultural and Food Chemistry, 53, 973981.

Prachayawarakorn, J., \& Pomdage, W. (2014). Effect of carrageenan on properties of biodegradable thermoplastic cassava starch/low-density polyethylene composites reinforced by cotton fibers. Materials \& Design, 61, 264-269. https://doi.org/ 10.1016/J.MATDES.2014.04.051

Rachmawati, N., Triwibowo, R., \& Widianto, R. (2015). Mechanical Properties and Biodegradability of AcidSoluble Chitosan-Starch Based Film. Squalen Bulletin of Marine \& Fisheries Postharvest \& Biotechnology, 10(1), 1-7.

Rajendran, N., Sharanya Puppala, Sneha Raj M., Ruth Angeeleena B., and Rajam, C. (2012). Seaweeds can be a new source for bioplastics. Journal of Pharmacy Research, 5(3), 1476-1479.

Razzaq, H. A. A., Pezzuto, M., Santagata, G., Silvestre, C., Larsen, N., \& Duraccio, D. (2016). Barley â-glucanprotein based bioplastic film with enhanced physicochemical properties for packaging. Food Hydrocolloids. j.foodhyd.2016.03.003

Šešlija, S., Nešiæ, A., Ružiæ, J., \& Krušiæ, M. K. (2017). Edible blend films of pectin and poly(ethylene glycol): Preparation and physicochemical evaluation. Food Hydrocolloids.https://doi.org/10.1016/ j.foodhyd.2017.10.027

Shimojo, M., Kojima, T., Nakajima, K., Hatta, K., Katoh, A., Kurita, K. (2010). Branched Chitins as Nonnatural Immunomodulatory Biopolymers: Secretions of TNFá and NO by Direct Stimulation of Macrophages. Biomacromolecules, 11, 1212-1216.

Slavutsky, A. M., \& Bertuzzi, M. A. (2014). Water barrier properties of starch films reinforced with cellulose nanocrystals obtained from sugarcane bagasse. Carbohydr Polym.,110, 53-61.

Sogiana, M. B., Tetty, K., \& Ahmad, S. (2013). Pencirian bioplastik tepung tapioka terplastisasi gliserol dengan penambahan karaginan. Institut Pertanian Bogor.

Winarno. (1996). Teknologi Pengolahan Rumput Laut. Jakarta: Pustaka Sinar Harapan.

Zhong, Q. P., Xia, W. S., Shah, U., Naqash, F., Gani, A., Masoodi, F. A., ... Hromis, N. (2008). Edible films and coatings: Sources, properties and application. Food Technol. Biotechnol., 46(3), 262-269. https://doi.org/ 10.5937/FFR1501011S 